Jurnal Penelitian Perawat Profesional

Volume 3 Nomor 1, Februari 2021

e-ISSN 2715-6885; p-ISSN 2714-9757

http://jurnal.globalhealthsciencegroup.com/index.php/JPPP

\title{
AROMA TERAPI LAVENDER UNTUK MENGATASI INSOMNIA PADA REMAJA
}

\author{
Ardila Putri Maharani \\ Fakultas Kedokteran, Universitas Lampung, Jl. Prof. DR. Ir. Sumatri Brojonegoro No.1, Gedong Meneng, \\ Kec. Rajabasa, Kota Bandar Lampung, Lampung, Indonesia 35145 \\ ardilaputri10@gmail.com (+6281215411224)
}

\begin{abstract}
ABSTRAK
Insomnia merupakan kesukaran dalam memulai dan mempertahankan tidur, sehingga seseorang tidak dapat memenuhi kebutuhan tidur yang sangat cukup, baik secara kuantitas maupun kualitas. Aromaterapi bertujuan untuk mempengaruhi suasana hati atau kesehatan seseorang, yang sering digabungkan dengan praktik pengobatan alternatif. Salah satu aromaterapi yang dapat mengatasi stres, gelisah, berdebar-debar, gugup, serta menciptakan perasaan tenang dan rileks adalah aromaterapi lavender. Minyak lavender dapat menimbulkan suasana hati yang tenang dan membuat tubuh rileks. Tujuan penelitian ini dilakukan untuk mengetahui apakah terdapat pengaruh pemberian aroma terapi terhadap insomnia pada remaja. Metode yang digunakan dalam penelitian ini adalah literature review. Artikel dikumpulkan berdasarkan referensi dari berbagai sumber Pubmed, Medscape, Google scholar dan WHO dengan kata kunci dalam pencarian jurnal seperti Aromatherapy lavender, effect aromatherapy to adult, dan manfaat aromaterapi pada insomnia remaja. Berdasarkan observasi kuesioner responden yang mengalami insomnia ringan sebagian besar menyatakan bahwa diketahui sebelum diberikan aromaterapi lavender, masih banyak remaja yang mengalami insomnia ringan. Responden mempunyai masalah kesulitan tidur pada pernyataan kesulitan untuk memulai tidur di malam hari $(61 \%)$, untuk pernyataan tiba-tiba terbangun pada malam hari $(88 \%)$. Pernyataan biasa terbangun lebih awal/ dini hari responden menjawab sebanyak $94 \%$, untuk pernyataan merasa mengantuk di siang hari (50\%), dan pernyataan sakit kepala pada siang hari (72\%). Penyebab lain gangguan tidur yang dialami oleh responden juga terdapat pada pernyataan merasa kurang puas dengan tidur dimalam hari (100\%), kemudian pada pernyataan bermimpi buruk sebanyak $83 \%$, untuk pernyataan badan merasa lemas, letih, kurang segar, kurang tenaga setelah tidur (66\%), dan pada pernyataan tidur selama 6 jam dalam semalam (56\%). Pemberian aromaterapi lavender (Lavandula angustifolla) dapat menurunkan derajat insomnia pada remaja dan dapat meningkatkan kualitas serta kebutuhan tidur pada remaja.
\end{abstract}

Kata kunci: aroma terapi; insomnia; manfaat

\section{LAVENDER AROMA THERAPY TO OVERCOME INSOMNIA IN ADOLESCENTS}

\footnotetext{
ABSTRACT

Insomnia is difficulty in initiating and maintaining sleep, so that a person cannot meet the needs of sufficient sleep, both in quantity and quality. Aromatherapy aims to influence a person's mood or health, which is often combined with alternative medical practices. One of the aromatherapy that can overcome stress, anxiety, palpitations, nervousness, and create a feeling of calm and relaxation is lavender aromatherapy. Lavender oil can create a calm mood and relax the body. The purpose of this study was to determine whether there is an effect of aromatherapy on adolescent insomnia. The method used in this research is literature review from various journals, then summarizes the current state of understanding about a topic. Journals are collected based on references from various sources Pubmed, Medscape, Google
} 
scholar and WHO with keywords in journal searches such as Aromatherapy lavender, the effect of aromatherapy to adult, and the benefits of aromatherapy on adolescent insomnia. Based on the observation of the questionnaire of respondents who experienced mild insomnia, most of them stated that before being given lavender aromatherapy, there were still many adolescents who experienced mild insomnia. Respondents have trouble sleeping on statements of difficulty starting to sleep at night (61\%), for statements suddenly waking up at night (88\%). The usual statement of waking up early / early morning, respondents answered as much as 94\%, for statements of feeling sleepy during the day (50\%), and statements of headache during the day (72\%). Other causes of sleep disorders experienced by respondents are also found in the statement that they are not satisfied with sleeping at night (100\%), then in the statement of nightmares as much as $83 \%$, for the statement that the body feels weak, tired, not refreshed, and lacks energy after sleeping (66\%), and on the statement slept for 6 hours a night (56\%). Giving lavender aromatherapy (Lavandula angustifolla) can reduce the degree of insomnia in adolescents and can improve the quality and need for sleep in adolescents.

Keywords: aroma therapy; benefits; insomnia

\section{PENDAHULUAN}

Remaja adalah individu yang berada pada tahap transisi antara masa kanakkanak menuju dewasa. Menurut Peraturan Menteri Kesehtan RI Nomor 25 Tahun 2014 kategori remaja adalah usia 10-18 tahun dan menurut Badan Kependudukan dan Keluarga Berencana (BKKBN). Pada masa remaja selalu disertai dengan perubahan fisiologi dan psikologi. Dimana perubahan fisiologi yaitu terjadinya perubahan secara fisik yang dialami oleh remaja, sedangkan pada perubahan psikologi yaitu terjadinya perubahan emosinal, prilaku, dan sikap (Ali \& Ansori, 2012).

Faktor yang memicu terjadinya insomnia pada remaja adalah faktor psikologi. Selain faktor psikologi, lingkungan dan gaya hidup juga dapat memicu terjadinya insomnia pada remaja. Tidak heran mengapa remaja dapat mengalami gangguan tidur, salah satu faktornya adalah menonton televisi hingga larut malam dan pemakainan alat elektronik seperti Hp serta Laptop. (Rimbawan, 2016).

Setiap individu memiliki kebutuhan istirhat dan tidur yang berdeda-beda, sesuai dengan aktivitas yang dilakukan. Sebagian besar remaja memerlukan tidur 7-8 jam waktu tidur malam. Hal ini bertujuan untuk mencegah keletihan dan kerentaan terhadap infeksi (Saputra, 2013). Insomnia merupakan kesukaran dalam memulai dan mempertahankan tidur, sehingga seseorang tidak dapat memenuhi kebutuhan tidur yang sangat cukup, baik secara kuantitas maupun kualitas (Berman \& Snyder, 2012).

\section{Berdasarkan World Health} Organization (WHO) menyebutkan bahwa 19 per miliar penduduk Jawa Tengah menderita stres yang memicu terjadinya insomnia. Tercatat 704.000 orang mengalami gangguan kejiwaan, dan 608.000 orang mengalami stres (Ulumuddin, 2011). National Sleep Foundation menyatakan bahwa Indonesia prevalensi penderita insomnia mencapai $70 \%$ paling sedikit seminggu sekali dan 30 juta orang sulit tidur setiap malamnya (Ulumuddin.B, 2011).

Angka prevalensi insomnia di Indonesia adalah $10 \%$ dari jumlah penduduk dan jumlah populasi atau sekitar 28 juta orang yang mengalami insomnia. Tingginya angka insomnia tersebut, dikaitkan dengan bertambahnya permasalahan yang terjadi dalam kehidupan, seperti depresi dan 
kecemasan pada seseorang (Life \& Style, 2017).

Tidur adalah suatu proses yang sangat penting bagi manusia, karena dalam tidur terjadi proses pemulihan, proses ini bermanfaat mengembalikan kondisi seseorang pada keadaan semula, dengan begitu, tubuh yang tadinya mengalami kelelahan akan menjadi segar kembali. Proses pemulihan yang terhambat dapat menyebabkan organ tubuh tidak bisa bekerja dengan maksimal, akibatnya orang yang kurang tidur akan cepat lelah dan mengalami penurunan konsentrasi (Ulimudiin, 2011).

Menurut Khaviri Tahun 2010 menjelaskan bahwa tidur yang baik merupakan kunci untuk merasa nyaman dan bahagia. Tidur yang buruk, sebaliknya, dapat mengakibatkan kelelahan, mudah tersinggung, mudah marah dan depresi klinis. Periode kekurangan tidur yang panjang, terkadang menyebabkan disorganisasi ego, halusinasi dan waham. Ia juga menyatakan orang yang kekurangan tidur REM mungkin menunjukan sikap mudah tersinggung dan letargi (merasa kehilangan energi dan antusiasme) (Kaplan dan Sadock, 2012).

Aromaterapi merupakan istilah genetik bagi salah satu jenis pengobatan alternatif yang menggunakan bahan cairan tanaman yang mudah menguap, dikenal sebagai esensial oil, dan senyawa aromatik lainnya dari tumbuhan. Aromaterapi bertujuan untuk mempengaruhi suasana hati atau kesehatan seseorang, yang sering digabungkan dengan praktik pengobatan alternatif (Parisa Yavari et al, 2013).

Salah satu aromaterapi yang dapat mengatasi stress, gelisah, berdebar- debar, gugup, serta menciptakan perasaan tenang dan rileks adalah aromaterapi lavender. Minyak lavender dapat menimbulkan suasana hati yang tenang dan membuat tubuh rileks (Jaelani, 2009).

Penggunaan aromaterapi bunga lavender (Lavandula angustifolla) salah satu dengan inhalasi untuk mendapatkan manfaat langsung ke dalam tubuh. Aromaterapi bunga lavender ini mengandung linool yang berfungsi sebagai efek sadatif sehingga ketika orang menghirup aromaterapi bunga lavender maka aroma yang dikeluarkan akan menstimulasi reseptor silia saraf olfactorius yang berada di epitel olfactory untuk menurunkan aroma tersebut ke bulbus olfactorius melalui saraf olfactorius. Bulus olfactorius berhubungan dengan sistem limbik. Dampak positif aromaterapi terhadap kualitas tidur yang nyenyak akan lebih dirasakan secara langsung (inhalasi) karena hidung mempunyai kontak langsung dengan bagian-bagian otak yang bertugas merangsang terbentuknya efek yang ditimbulkan aromaterapi (Jaelani, 2009).

Dampak positif aromaterapi terhadap kualitas tidur yang nyenyak akan lebih dirasakan secara langsung (inhalasi) karena hidung mempunyai kontak langsung dengan bagian-bagian otak yang bertugas merangsang terbentuknya efek yang ditimbulkan aromaterapi (Jaelani, 2009). Penelitian bertujuan untuk mengetahui apakah terdapat pengaruh pemberian aroma terapi terhadap insomnia pada remaja.

\section{METODE}

Metode yang digunakan dalam penelitian ini adalah literature review dari berbagai jurnal, kemudian meringkas kondisi pemahaman terkini 
tentang suatu topik. Jurnal dikumpulkan brdasarkan referensi dari berbagai sumber (Pubmed, Medscape, Google scholar dan WHO) dengan kata kunci dalam pencarian jurnal seperti Aromatherapy lavender, effect aromatherapy to adult, dan manfaat aromaterapi pada insomnia remaja. Jurnal yang didapatkan dari pencarian tersebut sebanyak 23 artikel. Kemudian artikel tersebut akan diringkas berdasarkan publikasi terbaik dan palin relevan untuk kemudian dibandingkan dengan hasil yang disajikan dalam artikel.

\section{HASIL}

Berdasarkan penelitian kuesioner responden yang mengalami insomnia ringan sebagian besar menyatakan bahwa diketahui sebelum diberikan aromaterapi lavender, masih banyak remaja yang mengalami insomnia ringan. Responden mempunyai masalah kesulitan tidur pada pernyataan kesulitan untuk memulai tidur di malam hari $(61 \%)$, untuk pernyataan tiba-tiba terbangun pada malam hari (88\%). Pernyataan biasa terbangun lebih awal/ dini hari responden menjawab sebanyak $94 \%$, untuk pernyataan merasa mengantuk di siang hari $(50 \%)$, dan pernyataan sakit kepala pada siang hari (72\%).Penyebab lain gangguan tidur yang dialami oleh responden juga terdapat pada pernyataan merasa kurang puas dengan tidur dimalam hari (100\%), kemudian pada pernyataan bermimpi buruk sebanyak $83 \%$, untuk pernyataan badan merasa lemas, letih, kurang segar, kurang tenaga setelah tidur (66\%), dan pada pernyataan tidur selama 6 jam dalam semalam (56\%).

\section{PEMBAHASAN}

Derajat insomnia yang dialami remaja putri sebelum diberikan aromaterapi lavender rata-rata mengalami insomnia ringan sebanyak 12 remaja (67\%). Selain itu, terdapat 6 remaja putri mengalami insomnia berat $(33 \%)$. Hal ini dikarenakan oleh beberapa faktor yang mempengaruhi insomnia yaitu perubahan fisiologi dan psikologis (Ali \& Ansori, 2012).

Berdasarkan observasi kuesioner responden yang mengalami insomnia ringan sebagian besar menyatakan bahwa diketahui sebelum diberikan aromaterapi lavender, masih banyak remaja yang mengalami insomnia ringan. Responden mempunyai masalah kesulitan tidur pada pernyataan kesulitan untuk memulai tidur di malam hari $(61 \%)$, untuk pernyataan tiba-tiba terbangun pada malam hari (88\%). Pernyataan biasa terbangun lebih awal/ dini hari responden menjawab sebanyak $94 \%$, untuk pernyataan merasa mengantuk di siang hari $(50 \%)$, dan pernyataan sakit kepala pada siang hari (72\%).Penyebab lain gangguan tidur yang dialami oleh responden juga terdapat pada pernyataan merasa kurang puas dengan tidur dimalam hari (100\%), kemudian pada pernyataan bermimpi buruk sebanyak $83 \%$, untuk pernyataan badan merasa lemas, letih, kurang segar, kurang tenaga setelah tidur $(66 \%)$, dan pada pernyataan tidur selama 6 jam dalam semalam (56\%). Hal ini sejalan teori menurut dr. Yekti Susilo dan Ari Wulandari (2011) yang menyatakan bahwa salah satu gejala dari insomsia yaitu perasaan sulit tidur, terbangun dini hari dan sering mengantuk disiang hari.

Selain itu menurut Widya (2010) ada 15 tanda-tanda umum apabila seseorang mengalami serangan insomnia yaitu, adanya gangguan tidur yang berfariasi dari ringan sampai parah, sulit jatuh dalam fase tidur, sering terbangun dimalam hari, saat terbangun sulit untuk tidur kembali, terbangun terlalu pagi, 
terbangun terlalu cepat, tidur yang tidak memulihkan, pikiran seolah dipenuhi berbagai hal, selalu kelelahan disiang hari, penat, mengantuk, sulit berkonsetrasi, emosi, merasatidak pernah mendapat tidur yang cukup, dan sering nyeri kepala.Setelah diberikan aromaterapi lavender selama 7 hari berturut-turut dengan durasi 30 menit setiap malamnya, sebagian besar responden yang semula mengalami derajat insomnia ringan kini menjadi tidak insomnia (67\%). Pada pernyataan kuesioner sebelumnya banyak responden menjawab tiap poin pernyataan yang pada awalnya presentasenya masih tinggi, kini presentase tersebut sudah menurun meskipun angka penurunannya tidak terlalu tinggi. Hal ini terlihat dari pernyataan tiba-tiba terbangun pada malam hari $(61 \%)$, pada pernyataan biasa terbangun lebih awal/ dini hari (72\%), dan pada pernyataan merasa kurang puas dengan tidur dimalam hari (56\%), serta pada pernyataan bermimpi buruk yaitu sebanyak $61 \%$.

Menurut Kaplan dan Sadock (2010), menyatakan bahwa insomnia adalah gangguan tidur yang dialami oleh penderita dengan gejala-gejala selalu merasa lelah dan letih sepanjang hari dan secara terus-menerus, mengalami kesulitan untuk tidur atau selalu terbangun di tengah malam dan tidak dapat kembali tidur.

Menurut Jaelani (2017), mengatakan bahwa aromaterapi lavender memiliki efek yang sangat bermanfaat bagi tubuh yaitu aromaterapi lavender mampu meredakan ketegangan otot-otot yang sedang mengalami kelelahan atau ketegangan akibat aktivitas yang berlebihan. Selain itu efek dari zat-zat aktifnya dapat mempengaruhi implusdan reflek saraf yang diterima oleh ujung-ujung reseptor saraf, dan dapat mempengaruhi aktivitas fungsi kerja otak melalui sistem saraf yang berhubungan dengan indera penciuman. Respons ini akan dapat merangsang peningkatan produksi masa penghantar saraf otak (neuratransmiter), yaitu yang berkaitan dengan pemulihan kondisi psikis (seperti emosi, perasaan, pikiran, dan keinginan). Hal ini sejalan dengan penelitian yang dilakukan oleh Kurnia, dkk (2009) dalam penelitian berjudul "Lavender Aromatherapy Improve Quality of Sleep in Eldery People" dimana aromaterapi lavender dapat mempengaruhi kualitas tidur sesorang pada insomnia.

\section{SIMPULAN}

Pemberian aromaterapi lavender (Lavandula angustifolla) dapat menurunkan derajat insomnia pada remaja dan dapat meningkatkan kualitas serta kebutuhan tidur pada remaja.

\section{DAFTAR PUSTAKA}

Ali M, Mohammad A. 2012. Psikologi Perkembangan Peserta Didik. Jakarta : PT. Bumi Aksara.

Arikunto, S. 2010. Suatau Pendekatan Praktek. Jakarta : Rineka Cipta.

Beman, A., Snyder. S. 2012. Fundamentals of Nursing : Concepst, Process, and Practice (9th ed). New Jersey : Pearson

Buckle J. 2015. Clinical Aromatherapy, Essential Oil in Healthcare, Third Edition.USA : Elsevier Inc.

Endang N. 2015. Terapi Alternatif dan Komplementer dalam Bidang Keperawatan. Bogor : IN MEDIA

Jaelani. 2009. Aromaterapi. Jilid Pertama. Edisi Peratama. Jakarta : Pustaka Populer Obor. 
Kaplan, H.I dan Sadock, B.J. 2010. Sinopsis Psikiatri. Jilid 2, edisi VII. Jakarta : Binatupa Aksara.

Koensoemardiyah. 2009. A-Z Aromaterapi untuk Kesehatan, Kebugaran, dan Kecantikan. Yogyakarta : Lily Publisher.

Ulumuddin BA. 2011. Hubungan Tingkat Stres dengan Kejadian Insomnia pada Mahasiswa Program Studi Ilmu Keperawatan Universitas Diponogoro. Jurnal : Fakultas Kedokteran Universitas Diponogoro.http://eprints.undip.a c.id/33160/10/Artikel_Hubungan_ Tingkat_Stres_dengan_Kejadian_ Insomnia.pdf

Yekti S dan Ari W. 2011. Cara Jitu Mengatasi Insomnia. Yogyakarta : ANDI Yogyakarta. 